\title{
Thyroid nodules and thyroid cancer in Graves' disease
}

\section{Nódulos tiroidianos e câncer de tiroide na doença de Graves}

Abbas Ali Tam', Cafer Kaya', Fevzi Balkan', Mehmet Kılıç², Reyhan Ersoy ${ }^{3}$, Bekir Çakır ${ }^{3}$

\begin{abstract}
Objective: The frequency of thyroid nodules accompanying Graves' disease and the risk of thyroid cancer in presence of accompanying nodules are controversial. The aim of this study was to evaluate the frequency of thyroid nodules and the risk of thyroid cancer in patients operated because of graves' disease. Subjects and methods: Five hundred and twenty-six patients in whom thyroidectomy was performed because of Graves' disease between 2006 and 2013 were evaluated retrospectively. Patients who had received radioactive iodine treatment and external irradiation treatment in the neck region and who had had thyroid surgery previously were not included in the study. Results: While accompanying thyroid nodule was present in 177 $(33.6 \%)$ of 526 Graves' patients, thyroid nodule was absent in $349(66.4 \%)$ patients. Forty-two $(8 \%)$ patients had thyroid cancer. The rate of thyroid cancer was $5.4 \%(n=19)$ in the Graves' patients who had no nodule, whereas it was $13 \%(n=23)$ in the patients who had nodule. The risk of thyroid cancer increased significantly in presence of nodule $(p=0.003)$. Three patients had recurrence. No patient had distant metastasis. No patient died during the follow-up period. Conclusions: Especially Graves' patients who have been decided to be followed up should be evaluated carefully during the follow-up in terms of thyroid cancer which may accompany. Ara Bras Endocrinol Metab. 2014;58(9):933-8
\end{abstract}

Keywords

Graves' disease; thyroid nodules; thyroid cancer

\section{RESUMO}

Objetivo: A frequência da ocorrência de nódulos tiroidianos acompanhando a doença de Graves e o risco de câncer de tiroide na presença desses nódulos é controversa. 0 objetivo deste estudo foi avaliar a frequência de nódulos tiroidianos e o risco de câncer de tiroide em pacientes operados por doença de Graves. Sujeitos e métodos: Quinhentos e vinte e seis pacientes anteriormente submetidos à tiroidectomia por doença de Graves entre 2006 e 2013 foram avaliados retrospectivamente. Os pacientes que receberam tratamento com iodo radioativo e irradiação externa da região do pescoço e que anteriormente passaram por cirurgia de tiroide não foram incluídos no estudo. Resultados: Enquanto os nódulos de tiroide se apresentaram em $177(33,6 \%)$ dos 526 pacientes com doença de Graves, eles estiveram ausentes em 349 (66,4\%) pacientes. Um total de 42 (8\%) dos pacientes teve câncer de tiroide. A ocorrência de câncer de tiroide foi $5,4 \%$ ( $n=19$ ) nos pacientes com doença de Graves que não apresentaram nódulos, e $13 \%$ ( $n=23$ ) nos pacientes com nódulos. 0 risco de câncer de tiroide aumentou significativamente na presença de nódulos $(p=0,003)$. Três pacientes apresentaram recidivas. Nenhum paciente apresentou metástase distante e nenhum paciente veio a óbito durante o período de acompanhamento. Conclusões: Pacientes com doença de Graves devem ser avaliados cuidadosamente no acompanhamento para a possível ocorrência de câncer de tiroide. Arq Bras Endocrinol Metab. 2014;58(9):933-8

Descritores

Doença de Graves; nódulos tiroidianos; câncer de tiroide
${ }^{1}$ Ataturk Training and Research Hospital, Department of Endocrinology and Metabolism, Ankara, Turkey ${ }^{2}$ Yıldırım Beyazıt University, Department of General Surgery, Ankara, Turkey ${ }^{3}$ Yıldırım Beyazıt University, Department of Endocrinology and Metabolism, Ankara, Turkey

Correspondence to: Abbas Ali Tam Ataturk Training and Research Hospital

06800 - Ankara, Turkey endoali@hotmail.com

Received on June/30/2014 Accepted on Aug/21/2014

DOI: 10.1590/0004-2730000003569 


\section{INTRODUCTION}

$\mathrm{T}$ hyroid nodules are frequently found in patients with Graves' disease, though the frequency varies depending on the method used (1-3). The prevalence of palpable thyroid nodule is 3 -fold higher compared to the general population. In epidemiological studies, a higher thyroid nodule prevalence is found when thyroid ultrasonography is used for evaluation of thyroid morphology (2).

In addition, thyroid nodule develops in approximately half of the patients with Graves' disease during the follow-up (4). There is an increased risk of thyroid cancer in presence of these nodules (3).

While the rate of malignancy is approximately $5 \%$ in palpable thyroid nodules in the general population, it varies between $2.3 \%$ and $45.8 \%$ in patients with Graves' disease (2).

Moreover, there has been much controversy regarding biological behaviour of cancers in Graves' patients. While some authors have reported that thyroid cancers have a more agressive course $(5,6)$, some others have reported the contrary $(7,8)$. The aim of this study was to investigate the frequency of thyroid nodule in patients operated because of Graves' disease and the frequency of thyroid cancer in patients with and without nodule.

\section{SUBJECTS AND METHODS}

Five hundred and twenty-six patients who underwent thyroidectomy because of Graves' disease between 2006 and 2013 were included in the study. The diagnosis of Graves' disease was made with increased serum triiodothyronine (T3) and thyroxine (T4) levels and decreased thyroid stimulating hormone (TSH) levels and diffuse uptake on thyroid scintigraphy in patients who had a history and signs of hyperthyroidism. In most cases, the diagnosis was supported with increased thyroid stimulating antibody (TRAb) levels. Thyroid ultrasonography was performed in all patients. The patients were divided into two groups as the group with nodule and the group without nodule according to presence of thyroid nodule. Fine needle aspiration biopsy (FNAB) was performed in 172 of the patients who had thyroid nodule. Patients who had received radioactive iodine treatment and external irradiation treatment in the neck region and who had had thyroid surgery previously were not included in the study.
The patients were treated with propylthiouracil or methimazole before surgery. The patients who required urgent surgery received Lugol solution for 7-10 days before surgery. The indications for surgery in Graves' patients included failure of antithyroid drug treatment and/or development of side effects due to these drugs, goitre which caused to compression symptoms in the trachea or esophagus, severe opthalmopathy, suspicious malignancy on FNAB and request of the patient. Total or near total thyroidectomy was performed in all patients.

\section{RESULTS}

Five hundred and twenty-six patients 352 (66.9\%) of whom were female and $174(33.1 \%)$ of whom were male were included in the study. The mean age of the patients was $41.2 \pm 12.4$ years (range 17-69 years). While thyroid nodule was present in 177 (33.6\%) patients, $349(66.4 \%)$ had no thyroid nodule. Among the patients who had thyroid nodule, 16 had solitary nodule and 161 had multiple nodules. The mean nodule diameter was $27.17 \pm 14.10 \mathrm{~mm}$ (range 7.30-68.0 mm). One hundred and twenty $(68.2 \%)$ of the patients who had thyroid nodule were female, whereas 57 (31.8\%) were male and there was no statistically significant difference $(\mathrm{p}>0.05)$ (Table 1$)$. According to the largest nodule diameter, the thyroid nodule diameter was higher than $1 \mathrm{~cm}$ in 171 of 177 patients.

Table 1. Clinical characteristics of patients

\begin{tabular}{lcc}
\hline Gender & $\mathbf{n}$ & \% \\
\hline Female & 352 & 66.9 \\
Male & 174 & 33.1 \\
\hline Nodule status & $\mathbf{n}$ & $\mathbf{\%}$ \\
\hline Without nodule & 349 & 66.4 \\
With nodule & 177 & 33.6 \\
$\quad$ Solitary nodule & 16 & 9.0 \\
Multiple nodules & 161 & 91.0 \\
Female & 120 & 68.2 \\
$\quad$ Male & 57 & 31.8 \\
\hline
\end{tabular}

Thyroid cancer was found in $42(8 \%)$ patients. All cancers had papillary origin; $33(78.6 \%)$ of these were papillary microcarcinoma and $9(21.4 \%)$ were papillary carcinoma. When the patients were divided into two groups as the group with thyroid nodule and the group without thyroid nodule, thyroid cancer was found in $13 \%$ of 177 patients $(n=23)$ who had thyroid nodule 
and in $5.4 \%(\mathrm{n}=19)$ of 349 patients who had no thyroid nodule. This difference was statistically significant $(\mathrm{p}=0.003)$. The risk of cancer increased markedly in presence of thyroid nodule. In our study, thyroid cancer was present in $2(12.5 \%)$ of 16 patients who had a solitary nodule and in 21 (13\%) of 161 patients who had multiple thyroid nodules.

A total of 17 patients had variant thyroid cancer 6 of whom had classical variant, 3 of whom had oncocytic variant and 2 of whom had tall cell variant. The mean age of 42 patients who were found to have cancer was $43.1 \pm 12.4$ years (range 20-69 years). The mean age was $44.8 \pm 12.1$ years (range 22-69 years) in women who had thyroid cancer and $40.2 \pm 12.8$ years (range 20-61 years) in men who had thyroid cancer. This difference was not statistically significant $(p>0,05)$. In the patients who were found to have thyroid cancer, the mean follow-up time between the diagnosis of Graves' disease and surgery was $3.95 \pm 1.61$ years (range 1-8 years) and the mean follow-up time after the diagnosis of thyroid cancer was $2.87 \pm 1.61$ years (range 0.5 7.50 years). Anti-Tg and Anti TPO were measured in nearly all patients with cancer and they were found to be positive in $52.5 \%$ of the patients and $48.8 \%$ of the patients, respectively (Table 2 ). FNAB was performed in 172 patients who had thyroid nodule and suspicious malignancy was present in 2 of them.

Table 2. Clinical characteristics of cancer patients

\begin{tabular}{llcc}
\hline Characteristic & & $\mathbf{n}$ & \% \\
\hline Gender & Male & 16 & 38.1 \\
& Female & 26 & 61.9 \\
Anti-Tg & Positive & 21 & 52.5 \\
& Negative & 19 & 47.5 \\
Anti-TPO & Positive & 20 & 48.8 \\
& Negative & 21 & 51.2 \\
Age (years) & & $43.1 \pm 12.4$ & \\
Male & & $40.2 \pm 12.8$ & \\
Female & $44.8 \pm 12.1$ & \\
Disease period (years) $^{\text {Cancer period }}$ (years) & & $3.95 \pm 1.61$ & \\
C & $2.87 \pm 1.61$ & \\
\hline
\end{tabular}

Data is expressed as mean $\pm \mathrm{SD}$; with the range presented in parenthesis a: the mean time between Graves' disease and operation. b: the mean follow-up time after the diagnosis of thyroid cancer.

Lymph node involvement was present in 3 (7.1\%) of 42 patients who had thyroid cancer, thryoid capcule invasion was present in $6(14.3 \%)$, invasion into the surrounding tissues was present in $4(9.5 \%)$ and recurrence occured in $3(7.1 \%)$. The tumor was multicentric in 5 patients. Cancer was present in both lobes in 5 patients. Three of 3 patients who had lymph node involvement, 3 of 6 patients who had thyroid capsule invasion and 2 of 4 patients who had invasion into the surrounding tissues had papillary thyroid cancer and the rest had micropapillary thyroid cancer (Table 3 ).

Table 3. Clinical characteristics of cancer patients

\begin{tabular}{llc}
\hline & $\mathbf{n}$ & $\%$ \\
\hline Lymph node metastasis & 3 & 7.1 \\
PTC & 3 & 100.0 \\
MPTC & 0 & 0.0 \\
Mulicentricity & 5 & 11.9 \\
PTC & 2 & 40.0 \\
MPTC & 3 & 60.0 \\
Thyroid capsule invasion & 6 & 14.3 \\
PTC & 3 & 50.0 \\
MPTC & 3 & 50.0 \\
Surrounding tissue invasion & 4 & 9.5 \\
PTC & 2 & 50.0 \\
MPTC & 2 & 50.0 \\
Bilaterality & 5 & 11.9 \\
PTC & 4 & 80.0 \\
MPTC & 1 & 20.0 \\
Recurrence & 3 & 7.1 \\
PTC & 2 & 66.6 \\
MPTC & 1 & 33.4 \\
\hline
\end{tabular}

PTC: papillary thyroid cancer; MPTC: micropapillary thyroid cancer.

Recurrence occured in only one of 33 micropapillary thyroid cancers and in 2 of 9 papillary thyroid cancers. According to TNM staging, 37 patients had stage 1. Thirty-two of 33 micropapillary thyroid cancers were stage 1 and one was stage 2 . Five of 9 papillary thyroid cancers were stage 1,1 was stage 2, 2 were stage $4 \mathrm{a}$ and 1 was stage $4 \mathrm{~b}$ (Table 4 ).

There was no statistically significant difference between the patients with thyroid cancer who showed and did not show lymph node invasion, thyroid capsule invasion, invasion into the surrounding tissues and recurrence in terms of age, TRAb titer and disease time $(\mathrm{p}>0.05)$.

The cancer focus was in the parenchyma in $19 \mathrm{pa}-$ tients with toxic diffuse goitre. In addition, cancer was present in the parenchyma of 12 of the Graves' patients 
who had nodule. Thus, the cancer focus was found in the parenchyma in 31 (73.8\%) of 42 patients independent of accompanyment of thyroid nodule. Twenty-six cancers in the thyroid parancime were micropapillary. Mortality was not observed in any patient during the follow-up. Radioactive iodine treatment was given to 29 patients.

The data were assessed using SPSS 15.0 statistical package program. Chi-square and Fisher's exact test were used in assessment of the categorical data and Student's T-test and one-way variance analysis were used in assessment of the numerical data. $\mathrm{p}$ value of $<0,05$ was considered statistically significant.

Table 4. TNM staging in cancer patients

\begin{tabular}{lcc}
\hline TNM & $\mathbf{n}$ & \% \\
\hline Stage 1 & 37 & 88.0 \\
Stage 2 & 2 & 4.8 \\
Stage 4A & 2 & 4.8 \\
Stage 4B & 1 & 2.4 \\
Total & 42 & 100.0 \\
\hline
\end{tabular}

\section{DISCUSSION}

Thyroid nodule is observed with a higher rate in patients with Graves' disease compared to the general population. The prevalence of these nodules varies depending on the method used (examination, thyroid scintigraphy, thyroid ultrasonography or combinations of these). The prevalence is lower when only clinical examination and scintigraphy are performed compared to ultrasonography (9). Palpable thyroid nodules are observed with a rate of $5 \%$ in the general population and with a rate of approximately $15 \%$ in Graves' disease $(1,10)$. When more sensitive echographic imaging is used, thyroid nodules are found more frequently in Graves' disease compared to the general population (10).

Cantalamessa and cols. found thyroid nodule with a diameter of $8 \mathrm{~mm}$ or larger in $33.6 \%$ of Graves' patients. When smaller lesions were included, the figure reached to $40.6 \%$ (4).

Kraimps and cols. could detect thyroid nodule with palpation only in $40(28.6 \%)$ of 140 patients with thyroid nodule in their multicenter study which included 557 individuals. Scintigraphy revealed cold nodule in 54 patients $(38.6 \%)$, whereas ultrasonography could detect $116(82.9 \%)$ of these patients (3).
Kim and cols. detected thyroid nodule by palpation in $9.4 \%$ of the patients $(23 / 245)$ and by thyroid ultrasonography in $35.1 \%$ of the patients $(6 / 245)$ in a prospective study which they conducted with 245 Graves patients. Fifty percent of these patients $(43 / 86)$ had solitary nodules and $50 \%(43 / 86)$ had multiple nodules (11).

Our center is a reference center and we initially perform thyroid ultrasonography in all thyroid patients referring to our department. In our series, we detected thyroid nodule in a total of 177 (33.6\%) patients by thyroid ultrasonography; 16 of these patient had solitary nodule and 161 had multiple nodules. According to the size of the dominant nodule, 171 patients had a nodule larger than $1 \mathrm{~cm}$.

Presence of these nodules increases the risk of thyroid cancer. However, the risk of differentiated thyroid cancer in Graves patients remains as a controversial issue. The malignancy rate in these nodules varies between $10 \%$ and $46 \%(10)$. This rate is approximately $5 \%$ in the general population (12). While the annual incidence of clinical thyroid cancer in the general euthyroid population has been reported to be $0.5-8 / 100.000$, it is 175/100.000 in Graves disease (13).

Recently, Ren and cols. detected thyroid nodule in $22.7 \%$ of Graves patients $(96 / 423)$ by ultrasonography. Twenty five of these patients $(26 \%)$ had solitary nodule and $71(74 \%)$ had multiple nodules. In the same study, the total incidence of thyroid cancer was $13.7 \%$ $(58 / 423)$. While thyroid nodule accompanied to 46 of 58 patients, thyroid nodule was absent in $12(3,6 \%)$ patients and the tumor was detected incidentally (14).

In our study, the rate of thyroid cancer in Graves' patients was $8 \%(42 / 526)$. One of the important points in our series was the high cancer rate in the parenchyma of the patients with Graves' disease. There was a cancer focus in the thyroid parenchyma in $31(73.8 \%)$ of 42 patients. This finding is notable, because nearly all cancers reported in series of Graves' patients with coexisting carcinoma are in the thyroid nodule (1). Erbil and cols. (1) found that $67 \%(n=12)$ of thyroid cancers found incidentally in Graves' patients were in the parenchyma outside the nodule. Ren and cols. (14) reported this rate to be $3.6 \%(n=12)$. This shows that malignancy is not always related with nodule (12). If these patients were treated only with antithyroid and/ or radioactive iodine, they would not have received an appropriate treatment because of accompanying thyroid cancer (15). 
Thyroid cancers found in Graves' patients mostly have papillary origin (16). Many carcinomas related with Graves' disease are small and are found incidentally during surgery or postoperative pathological examination (17). In our study, all cancers detected in our study had papillary origin. Seventy-eight point six percent of these $(33 / 42)$ were micropapillary thyroid cancer.

The pathogenic relationship between Graves' disease and thyroid cancer could not be understood clearly. Thyrotropin receptor antibodies TRAbs may possibly play a role in the initiation and progression of thyroid cancer. TRAbs and TSH activate the same intracellular pathway and both of them have mitogenic and antiapoptotic effects on thyroid follicular cells. TRAbs stimulate angiogenesis, which has a critical role in the growth and development of the tumor in the thyroid, by upregulating vascular endothelial growth factor and placental growth factor $(2,10,13,18)$.

Biological behavior and optimal management of differentiated thyroid cancers accompanying Graves' disease are controversial (18). It has been reported that patients who have undergone thyroidectomy because of Graves' disease and who have small thyroid cancer (a diameter of $1 \mathrm{~cm}$ or smaller) have excellent prognosis and longer disease-free survival compared to patients who have small thyroid cancer without Graves' disease (19). Most of the patients in our series had small thyroid cancer. Thirty-seven of 42 patients had a TNM stage of 1 . Thirty-two of 33 patients with micropapillary thyroid cancer had a TNM stage of 1 and recurrence was observed in only one of these patients. In addition, no patient died during the follow-up.

Currently, antithyroid drugs, radioactive iodine and surgery are used as current treatment methods in treatment of Graves' disease. Each method has its own side effects and success and failure rates. The advantage of surgical treatment is that it improves thyrotoxicosis faster compared to the other methods and provides effective treatment (20). The recommended operation for Graves' disease is total thyroidectomy. Less extensive surgery (subtotal thyroidectomy) carries a considerable risk of recurrent thyrotoxicosis (up to $30 \%$ of the patients) and revisional thyroid surgery is related with a high complication risk (21). Therefore, total or near total thyroidectomy was performed in all patients in our series. Radioactive iodine treatment following surgery was given to 29 of our patients who were found to have thyroid carcinoma.
Conclusively, the risk of cancer is considerably increased in Graves' patients in presence of accompanying nodule. Our study included the patients in whom surgery was performed because of Graves' disease. Patients who were given radioactive iodine or medical treatment for treatment of Graves' disease were not included in our study. Studies including these patients are needed to demonstrate the frequency of thyroid nodules and the risk of cancer clearly in Graves' patients. The risk of cancer in the thyroid parenchyma in Graves' patients should not be ignored. Long-term treatment and follow-up of these patients in whom surgery has not been performed should be pursued meticulously not only for providing and maintaining the euthryoid state, but also because of increased risk of thyroid cancer.

Disclosure: no potential conflict of interest relevant to this article was reported.

\section{REFERENCES}

1. Erbil Y, Barbaros U, Ozbey N, Kapran Y, Tükenmez M, Bozbora A, et al. Graves' disease, with and without nodules, and the risk of thyroid carcinoma. J Laryngol Otol. 2008;122:291-5.

2. Belfiore A, Russo D, Vigneri R, Filetti S. Graves' disease, thyroid nodules and thyroid cancer. Clin Endocrinol. 2001;55:711-8.

3. Kraimps $\mathrm{JL}$, Bouin-Pineau MH, Mathonnet M, De Calan L, Ronceray $\mathrm{J}$, Visset $\mathrm{J}$, et al. Multicenter study of thyroid nodules in patients with Graves's disease. Br J Surg. 2000;87:1111-3.

4. Cantalamessa L, Baldini M, Orsatti A, Meroni L, Amodei V, Castagnone $D$. Thyroid nodules in graves disease and the risk of thyroid carcinoma. Arch Intern Med. 1999;159:1705-8.

5. Belfiore A, Garofalo MR, Giuffrida D, Runello F, Filetti S, Fiumara $A$, et al. Increased aggressiveness of thyroid cancer in patients with Graves' disease. J Clin Endocrinol Metab. 1990;70:830-5.

6. Pellegriti G, Belfiore A, Giuffrida D, Lupo L, Vigneri R. Outcome of differentiated thyroid cancer in Graves' patients. J Clin Endocrinol Metab. 1998;83:2805-9.

7. Pacini F, Elisei R, Di Coscio GC, Anelli S, Macchia E, Concetti R, et al. Thyroid carcinoma in thyrotoxic patients treated by surgery. $\mathrm{J}$ Endocrinol Invest. 1988;11:107-12.

8. Hales IB, McElduff A, Crummer P, Clifton-Bligh $P$, Delbridge L, Hoschl R, et al. Does Graves' disease or thyrotoxicosis affect the prognosis of thyroid cancer. J Clin Endocrinol Metab. 1992;75:886-9.

9. Mishra A, Mishra SK. Thyroid nodules in Graves' disease: implications in an endemically iodine deficient area. J Postgrad Med. 2001;47:244-7.

10. Pellegriti G, Mannarino C, Russo M, Terranova R, Marturano I, Vigneri $R$, et al. Increased mortality in patients with differentiated thyroid cancer associated with Graves' disease. J Clin Endocrinol Metab. 2013;98:1014-21.

11. Kim WB, Han SM, Kim TY, Nam-Goong IS, Gong G, Lee HK, et al. Ultrasonographic screening for detection of thyroid cancer in patients with Grave's disease. Clin Endocrinol. 2004;60:719-25.

12. Lima PC, Moura Neto A, Tambascia MA, Zantut Wittmann DE. Risk factors associated with benign and malignant thyroid nodules in autoimmune thyroid diseases. ISRN Endocrinol. 2013;25;2013:673146. 
13. Pazaitou-Panayiotou K, Michalakis K, Paschke R.Thyroid cancer in patients with hyperthyroidism. Horm Metab Res. 2012;44:255-62.

14. Ren $M, W u M C$, Shang $C Z$, Wang $X Y$, Zhang JL, Cheng $H$, et al. Predictive factors of thyroid cancer in patients with Graves' disease. World J Surg. 2014;38:80-7.

15. Weber KJ, Solorzano CC, Lee JK, Gaffud MJ, Prinz RA. Thyroidectomy remains an effective treatment option for Graves' disease. Am J Surg. 2006;191:400-5.

16. Boostrom S, Richards ML. Total thyroidectomy is the preferred treatment for patients with Graves' disease and a thyroid nodule. Otolaryngol Head Neck Surg. 2007;136:278-81.

17. Chao TC, Lin JD, Chen MF. Surgical treatment of thyroid cancers with concurrent Graves disease. Ann Surg Oncol. 2004;11:407-12.
18. Lee J, Nam KH, Chung WY, Soh EY, Park CS. Clinicopathologic features and treatment outcomes in differentiated thyroid carcinoma patients with concurrent Graves' disease. J Korean Med Sci. 2008;23:796-801.

19. Kikuchi S, Noguchi S, Yamashita H, Uchino S, Kawamoto H. Prognosis of small thyroid cancer in patients with Graves' disease. $\mathrm{Br}$ J Surg. 2006;93:434-9.

20. Phitayakorn R, Morales-Garcia D, Wanderer J, Lubitz CC, Gaz RD, Stephen AE, et al. Surgery for Graves' disease: a 25-year perspective. Am J Surg. 2013;206:669-73.

21. Tamatea JA, Tu'akoi K, Conaglen JV, Elton MS, Meyer-Rochow GY. Thyroid cancer in Graves' disease: is surgery the best treatment for Graves' disease? ANZ J Surg. 2012;84:231-4. 